Article

\title{
Impact of Pre-Sowing Red Light Treatment of Sweet Corn Seeds on the Quality and Quantity of Yield
}

\author{
Agata Dziwulska-Hunek ${ }^{1}\left[\right.$, Mariusz Szymanek ${ }^{2, *}{ }^{\circledR}$ and Joanna Stadnik ${ }^{3}(\mathbb{C}$ \\ 1 Department of Biophysics, University of Life Sciences in Lublin, Akademicka 13, 20-950 Lublin, Poland; \\ agata.dziwulska-hunek@up.lublin.pl \\ 2 Department of Agricultural, Forest and Transport Machinery, University of Life Sciences in Lublin, \\ Głęboka 28, 20-612 Lublin, Poland \\ 3 Department of Animal Raw Materials Technology, University of Life Sciences in Lublin, Skromna 8, \\ 20-704 Lublin, Poland; joanna.stadnik@up.lublin.pl \\ * Correspondence: mariusz.szymanek@up.lublin.pl; Tel.: +48-81-531-97-37
}

Received: 2 April 2020; Accepted: 10 May 2020; Published: 12 May 2020

check for updates

\begin{abstract}
This paper presents the results of a study on the effects of red light treatment of sweet corn seeds on the quantity and quality of the subsequent yield (total and marketable), as well as the length of cobs and thousand kernel weight. The respective groups of kernels were exposed to light: 1-once (K1), 2-twice (K2), and 3-thrice (K3); the control seeds were untreated. The light treatment had a positive impact on the analyzed values. Relative to the control, we observed a yield increase of approx. $5 \%$ for the Basin cultivar and approx. $25 \%$ for the Shaker and Powerhouse cultivars under the $\mathrm{K} 2$ mode. We also recorded an increase in the percentage of marketable yield of approx. $20 \%, 45 \%$, and $48 \%$, respectively for the Shaker, Powerhouse, and Basin cultivars. Positive effects were also observed in terms of cob length and thousand kernel weight for all treatment modes and cultivars analyzed. The obtained results support the inclusion of this method in the scope of recommendable agrotechnical practices aimed at improving the quantity and quality of yields of various crops and vegetables.
\end{abstract}

Keywords: corn; quantity and quality of yield; cob length; thousand kernel weight; red light radiation

\section{Introduction}

Corn is among the most widespread cereals cultivated worldwide. Its kernels are rich in protein, saccharose, as well as various vitamins and minerals [1]. Therefore, it is widely used in human nutrition and provides a valuable source of good quality livestock fodder. Its popularity as a crop continues to grow thanks to its short vegetation cycle and good economic potential. The growth, quality, and quantity of yields are influenced by weather conditions, particularly temperatures during the vegetation stage, as well as the applied agrotechnical treatment and fertilization. Suppression of corn growth is often due to excessive watering. Disproportionate availability of water results in kernels filling up and limits root growth [2,3]. Moreover, sweet corn, particularly at the onset of vegetation, is ill-equipped to effectively compete with weeds, which can reduce yield by up to $85 \%$ and hamper overall quality of corn produce [2,4].

The main task of seed cultivations is to provide sufficient sowing material, and efforts continue to be made with the view of improving on the existing cultivation technologies. High quality sowing material ought to ensure cultivar purity, be healthy, and show adequate sprouting capacity and vigor. Once harvested, corn seeds undergo various treatments to improve their quality, including priming, granulating (coating), and conditioning. At the same time, due the excessive use of chemicals in agriculture, there is a growing demand for eco-friendly food produce [5]. Consumers want their food 
products to be safe and healthy. Hence, physical, environmentally-friendly methods of seed treatment have been gaining considerable popularity [6]. Their purpose is to trigger physiological and biochemical changes in the seeds, and ultimately increase their vigor. In simplified terms, physical factors transfer various forms of energy into cells, which stimulates enzymatic and biochemical reactions leading to accelerated sprouting. It has been confirmed that the application of certain physical stimulants (laser light, magnetic and electric fields, gamma radiation, etc.) can have a positive impact on some plant properties (seed sprout rate, plant emergence and development, fresh mass increase, harvest yield, etc.) [6-16].

Laser light stimulation takes advantage of the seeds' capacity for absorbing and storing light energy and subsequently converting it into chemical energy. The energy facilitates the process of sprouting as well as the subsequent growth and development of plants. Despite the recent scientific and technological advances in this area, the exact mechanism of laser light's effect on seeds has yet to be fully explained $[5,11,17]$.

Pre-sowing treatment of seeds affects sprout rates and seedling growth, which in turn conditions the resulting harvest yield, nutrient content, and capacity to absorb sunlight $[1,6,18]$. The advantage of physical treatment methods stems from the fact that while the yield increase is maintained, the methods are also safe to the natural environment, which was what first drew us to this research topic. It is noteworthy that sunlight is indispensable in the processes of photosynthesis, and as such has a considerable bearing on the growth and development of plants. Unavailability of sufficient sunlight negatively affects harvest yields and leads to premature leaf aging, which is an indicator of the final stage in the plant life cycle [19]. The observed shortage of studies pertaining to the impact of pre-sowing red light stimulation on the quantity and quality of corn yields inspired us to explore this particular research problem. The aim of the present study was to determine the impact of pre-sowing red light treatment of corn seeds on the harvest yield and corn quality.

\section{Material and Methods}

\subsection{Plant Material}

The study was conducted at the Plant Biotechnology Laboratory of the University of Life Sciences in Lublin (51 $\left.{ }^{\circ} 13^{\prime} 21.9^{\prime \prime} \mathrm{N}, 22^{\circ} 37^{\prime} 55.85^{\prime \prime} \mathrm{E}\right)$, in 2018 and 2019. The research material was composed of corn seeds of two supersweet cultivars: Shaker and Basin provided by Seminis Vegetable Seeds, and one sweet cultivar-Powerhouse from Seminis. The seeds were obtained from the Institute of Seed Cultivation and Plant Acclimatisation in Radzików.

\subsection{Light Treatment Method}

The seeds were subjected to light treatment one day before sowing in one (K1), two (K2), or three (K3) times, using red light with the wavelength of $650-670 \mathrm{~nm}$ and flux density of $110-130 \mathrm{~W} \cdot \mathrm{m}^{-2}$. The control consisted of a batch of untreated seeds (Control).

The time of irradiation of light of a single corn grain was $0.1 \mathrm{~s}$. The time interval between subsequent exposure times of $\mathrm{K} 2$ and $\mathrm{K} 3$ was about $10 \mathrm{~s}$.

The pre-sowing treatment of the seed material entailed exposure on both sides of a single layer of seeds to direct red light. The device used for this purpose (Figure 1) consisted of a dispenser (a) with an outlet hole (b), a vibrating chute (c) with an adjustable element at the end (d) to control the gap (e) between the element and the edge of the chute (c). Below the chute, at least two halogen floodlights (g) were mounted on the device's frame (h). A vibrator (i) was installed on the chute (3). Pre-sowing treatment is typically applied to crop seeds with the view of improving the quality and quantity of harvest yields [20]. 


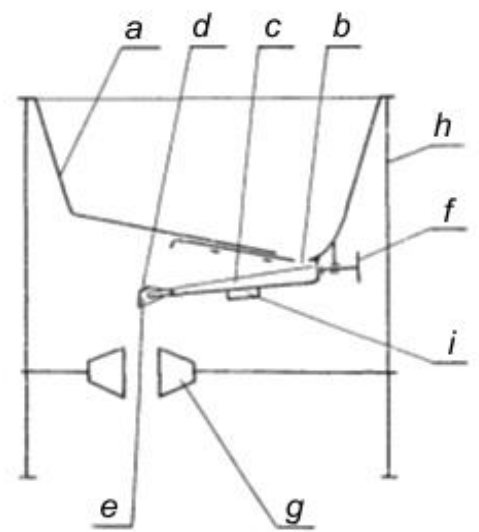

Figure 1. Light treatment device: a-hopper, b-outlet, $\mathrm{c}$-chute, $\mathrm{d}$-adjustable element, e-gap, $\mathrm{f}$-adjustment screw, g-halogen floodlights, $\mathrm{h}$ - cover, i-vibration actuator.

\subsection{Field Experiment and Date Collections}

The soil in the experimental field was composed of mollisols-loamy sands which are slightly acidic. The field was ploughed and prepared for sowing with a single pass of a disk-harrow. The experiment was set up as a randomized complete block design with four replications. Each plot area was $25 \mathrm{~m}^{2}$ $(10 \mathrm{~m} \times 2.5 \mathrm{~m})$ and consisted of four rows. The distance between rows was $70 \mathrm{~cm}$ and intra row spaces were $20 \mathrm{~cm}$. At sowing, $100 \mathrm{~kg} \cdot \mathrm{ha}^{-1}$ pure N, P, and K (15-15-15 composite) was applied on each plot, followed by $200 \mathrm{~kg} \cdot \mathrm{ha}^{-1} \mathrm{~N}$ as urea $(46 \% \mathrm{~N})$ applied at the 6 leaf stage. The fertilizer was placed $5 \mathrm{~cm}$ to the side of the seed row at a depth of $4 \mathrm{~cm}$.

The course of weather conditions in the growing seasons 2018-2019 was very diverse, especially in terms of precipitation. The vegetation period in 2018 began in very favorable humidity conditions. A moist and warm May was conducive to the vegetative development of plants, but during the period of greatest demand for water for corn (turn of July and August), its deficit occurred. In the vegetation period of 2019, a favorable temperature pattern during maize growth was noted. However, this season proved to be unfavorable in terms of the amount and distribution of precipitation; it began after almost two months (April and May). July was relatively humid, while August was very dry.

Cobs were harvested at the stage of milk maturity of kernels, which was at the end of August (2018) and the beginning of September (2019). The moisture content of the sweet corn kernels sample was determined gravimetrically by oven drying the sample at $103^{\circ} \mathrm{C}$ for $72 \mathrm{~h}$ until a constant weight was obtained. The result was expressed as percent moisture loss (wet basis).

During the harvest there was determined:

- Total and marketable leafless corn cobs yield (t.ha ${ }^{-1}$ ) according to the norm PN-R75377: 1996 [21],

—corn cobs length $(\mathrm{cm})$, and

一thousand kernel weight ( $\mathrm{g}$ ).

The marketable sweet corn cobs were healthy, straight in shape, and had a high degree of kernel filling.

Thirty corn cobs were sampled randomly from every combination to obtain kernels.

The thousand kernel weight (TKW) was determined using the laboratory scale (RADWAG WPS 36, PL).

\subsection{Statistical Analysis}

The obtained results were processed with the use of variance analysis. Where significant discrepancies between objects were identified on the basis of the significance test $F$, quantitative inference was performed relative to Tukey's confidence intervals for the significance threshold of $p<0.05$. The accuracy of the respective measurement results was established by considering the additional 
ranges of $95 \%$ confidence intervals for the arithmetic mean. Calculations were conducted with the use of STATISTICA 12.0 PL (StatSoft Poland) software (Figures 2-5).

\section{Results}

\subsection{Yield and Corn Cobs Quality}

Three different corn cultivars were analyzed in terms of yield and corn cobs quality of plants grown from seeds subjected to pre-sowing red light treatment. The average moisture content of sweet corn kernels for the Powerhouse variety was $74.6 \%$, for Shaker $75.8 \%$, and for Basin $75.9 \%$ in 2018 and $74.9 \%, 75.4 \%$, and $76.2 \%$ in 2019 , respectively. The statistical analysis showed significant statistical differences between varieties, but did not show significant differences between exposure times within the same variety.

The statistical analysis (Figures 2-5) confirmed the existence of significant differences in terms of the analyzed independent variables (number of light exposures, cultivar). Due to the fact that the statistical analysis did not show significant statistical differences between the analyzed results in 2018 and 2019, figures for mean values from two years were presented. Overall, the pre-sowing light treatment of the seeds had a positive influence on total yield. The highest impact (Figure 2) was observed for Powerhouse and Shaker seeds exposed to 2 consecutive treatments, respectively $25 \%$ and $24 \%$ relative to the control. In the case of the Basin cultivar, the highest yield was observed for seeds subjected to a single exposure and was $9 \%$ higher than the corresponding yield from untreated seeds.

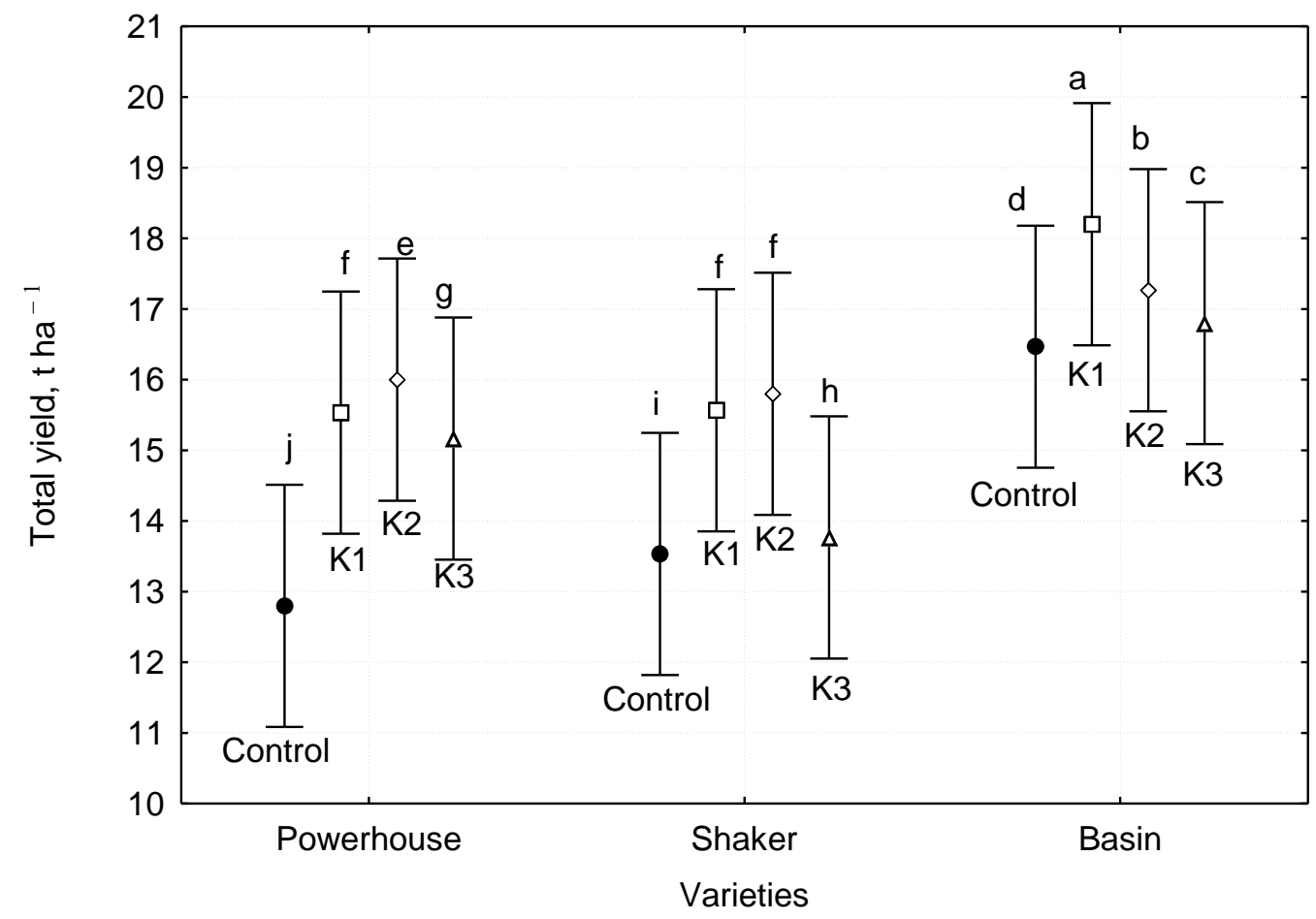

Figure 2. Changes of mean corn cobs yield values with $95 \%$ confidence intervals relative to the number of light exposures and respective maize cultivars (mean of two years). Means with the same letter are not significantly different from each other ( $p<0.05$-ANOVA followed by Tukey test). Error lines represent \pm standard deviation of the mean.

After the applied red light treatment, an increase was observed in the corn kernel content corresponding to marketable yield for all cultivars relative to the control (Figure 3). The highest marketable yields were obtained after K1 treatment for Powerhouse (45\%) and Basin (48\%) cultivars, and after K2 treatment for Shaker plants (20\%)—compared to the control. In turn, the lowest yield 
increase was observed after K2 treatment for Powerhouse (6\%) and after K3 treatment for Basin (36\%) and Shaker ( $4 \%)$ plants.

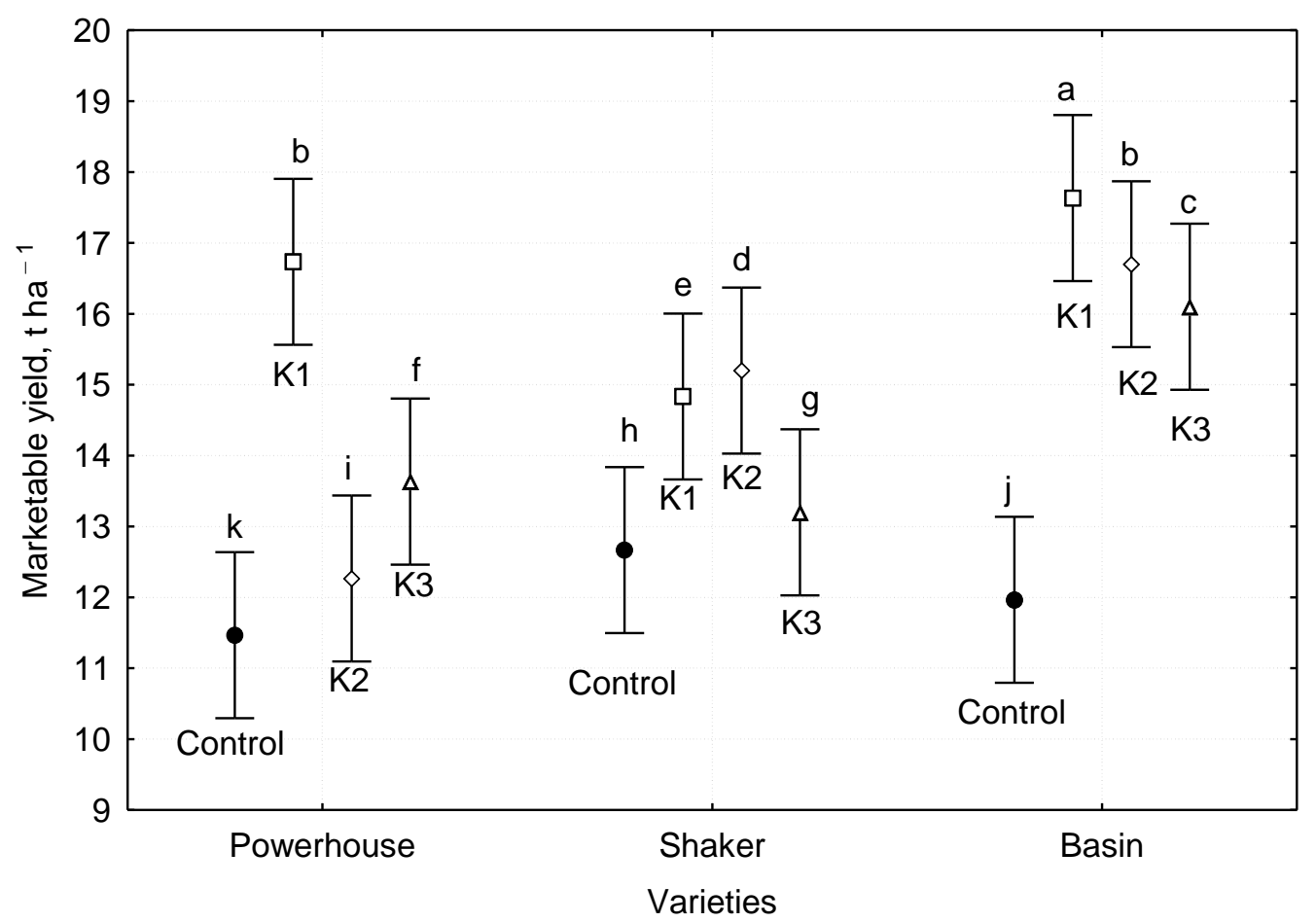

Figure 3. Mean values for marketable yield with $95 \%$ confidence intervals relative the number of light exposures and respective corn cultivars (mean of two years). Means with the same letter are not significantly different from each other $(p<0.05$-ANOVA followed by Tukey test). Error lines represent \pm standard deviation of the mean.

\subsection{Corn Cobs' Length}

Figure 4 illustrates the impact of red light treatment on the length of corn ears. The obtained results confirmed the existence of significant differences between the respective replicates of light exposure and corn cultivars.

Under the influence of the applied of light with seeds, changes in the length of the cobs were found in all varieties relative to the control (Figure 4). At K1, an increase of $14.3 \%$ for Powerhouse, $12 \%$ for Basin, and $4.9 \%$ for Shaker was observed. On the other hand, with K2 for the Powerhouse, Shaker, and Basin varieties, by approx. $6.9 \%, 9.6 \%$, and $8.1 \%$, respectively, and with K3 by approx. $10.3 \%, 3.2 \%$, and $6.1 \%$, respectively.

\subsection{Thousand Kernel Weight}

The changes in the thousand kernel weight were recorded relative to the number of light exposures and plant cultivars (Figure 5).

The TKW was similar for all three cultivars analyzed. After 3-time light exposure, the weight was roughly the same, approx. $470 \mathrm{~g}$. For two of the cultivars, Powerhouse and Basin, this was the highest value obtained. In the case of Shaker plants, the best effect was recorded for the K2 treatment. 


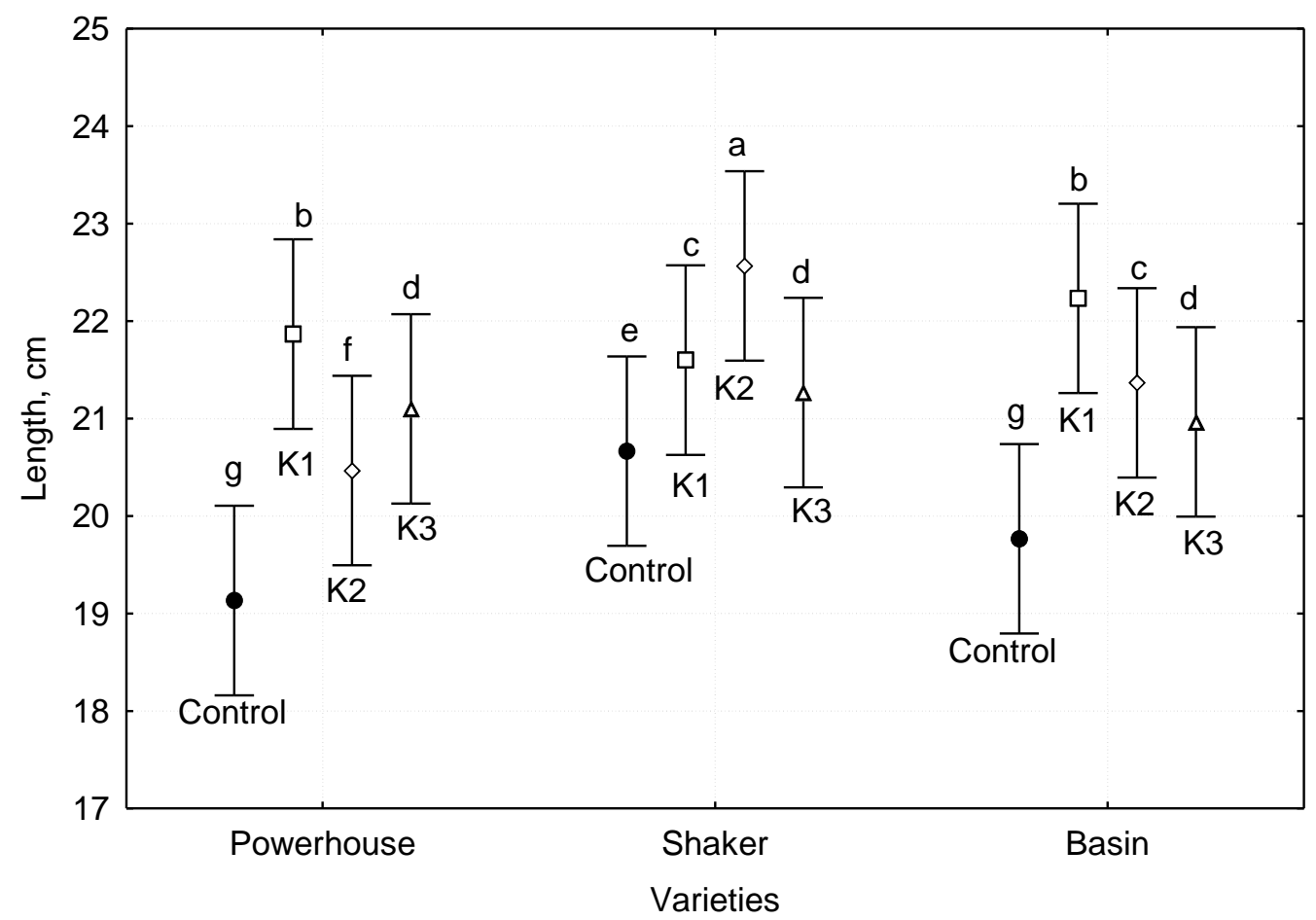

Figure 4. Changes in cobs length with $95 \%$ confidence intervals relative to the number of light exposures and respective cultivars (mean of two years). Means with the same letter are not significantly different from each other ( $p<0.05-$ ANOVA followed by Tukey test). Error lines represent \pm standard deviation of the mean.

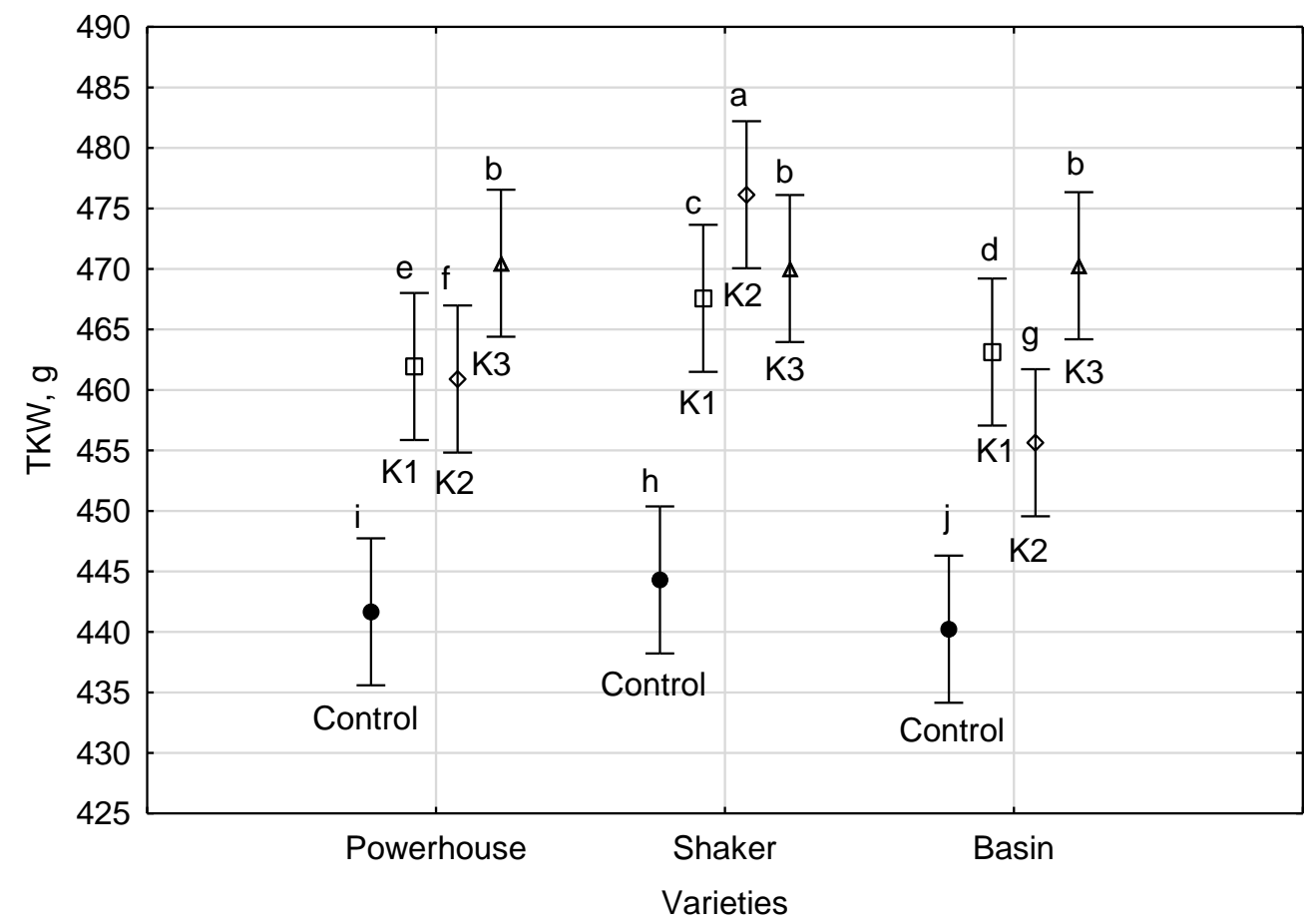

Figure 5. The thousand kernels weight (TKW) changes with $95 \%$ confidence intervals relative to the number of light exposures and respective cultivars (mean of two years). Means with the same letter are not significantly different from each other $(p<0.05-$ ANOVA followed by Tukey test). Error lines represent \pm standard deviation of the mean. 


\section{Discussion}

\subsection{Yield and Cobs Quality}

Sunlight is a crucial element of the process of photosynthesis, which has a direct bearing on plant development and harvested yields [19,22]. Access to sufficient light is a necessary condition for sustainable and productive cultivation, particularly so in the case of maize [23]. Literature reports seem to indicate that the corn yields obtained from seeds subjected to blue laser light treatment were better than those recorded after treatment with other laser light types. The reasons could have been connected to exposure times and longer wavelengths used, which may have caused seed damage. It is noteworthy that laser light stimulation relies on absorption and storage of radiation energy inside the plant $[16,17]$. Thanks to photosynthesis, maize can produce highly efficient yields (over $95 \%$ dry mass). Hasan et al. [16] reported the best yield efficiency for maize seeds treated with red and blue laser light with $105 \mathrm{~s}$ exposure time, and green light—with $85 \mathrm{~s}$ exposure time. In our study, the applied red light treatment also correlated with increased corn yields. Hernandez et al. [10] observed a significant increase in seedling emergence for plants grown from seeds exposed to laser light with $30 \mathrm{~mW}$ light output and $660 \mathrm{~nm}$ wavelength.

The study conducted by Yang et al. [24] pertained to decreased intensity of sunlight and its impact on the deterioration of the harvest yield and kernel quality. In the study by Jia et al. [25], shading corn plants (thus reducing light intensity by $55 \%$ ) led to a decreased weight and quality of kernels, and in another experiment the yield from shaded plants was described as significantly lowered [19]. The study conducted by Dziamba et al. [26] regarding an $8 \%-26 \%$ increase in maize yield for irradiated grain. According to research by Makarska et al. [27] it was noted that the germination energy of wheat grains of the Rysa varieties was the highest for twice exposure (and amounted to approx. 334\%). Germination capacity of wheat was more even for all exposures (1-, 2-, and 3-time). In the research carried out by Wesołowski and Cierpuła [28], the effect of double exposure with He-Ne laser light on the growth of winter wheat grain yield was noted.

The yield from corn cultivations is affected by hydration, i.e., availability of water in amounts sufficient for the processes of vegetation. Proper watering is one of the key factors conditioning good harvests. Abbas and Ranjan [29] reported a 9\%-16\% increase in maize yield when additional hydration was provided, compared to cultivations without the same. Yet another study pertained to nitrogen-binding Azospirllum brasilense bacteria, whose presence had a positive impact on the quality and productivity of cultivations, regardless of the vegetation stage [30]. As reported by Hasan et al. [16], exposure of sowing material to radiation had a positive impact on corn yields. A particularly large improvement was observed after the use of blue laser light with $85 \mathrm{~s}$ exposure time and green light at $65 \mathrm{~s}$. Corn is also susceptible to various blights transmitted by seeds. Colonization of seeds by various fungal species decreases the sprout rate, vigor, and vitality of plants. Some Fusarium species are strongly toxic and can pose a threat to human and animal health. At the same time, research suggests that diode laser light treatment tends to decrease fungal presence in maize seeds [31].

The corn yield quantity and quality was observed to increase for corn seeds sown with a specific plant spacing of $45 \times 35 \mathrm{~cm}$, relative to other spacing dimensions $(45 \times 20 \mathrm{~cm}, 30 \times 30 \mathrm{~cm})$. Meanwhile, the green fodder yield was higher for smaller plant spacing. Studies have also been conducted in terms of viability of various fertilization techniques, and the use of 150:75:40 $\mathrm{kg} \mathrm{NPK} \mathrm{ha}^{-1}+10 \mathrm{t}$ manure was found to produce high corn yields and good quality fodder [32]. As reported in literature, the study conducted by Isaac et al. [12] confirmed the positive impact of magnetic field treatment on the sprouting rate and vigor of plants as well as length of roots. Moreover, both our own studies and reports by other authors also confirm positive effects of red light treatment $[10,16]$.

\subsection{Length of Corn Cobs}

Adequate cobs length, kernel weight, and density of plant distribution in the field are key parameters influencing the quantity and quality of yield [33]. 
In our experiment, the recorded cobs length was between 19.2 and $22.7 \mathrm{~cm}$. In another study conducted by Ranachandrappa et al. [32], it was reported that spacing seeds further apart $(45 \times 30 \mathrm{~cm})$ significantly influenced the length of corn cobs $(22.69 \mathrm{~cm})$. The value was similar to that obtained in our study for the Shaker cultivar after K2 treatment. In another experiment, the use of fertilizer containing nitrogen (at $40 \mathrm{~kg} \cdot \mathrm{ha}^{-1}$ ) and phosphorus $\left(40 \mathrm{~kg} \cdot \mathrm{ha}^{-1}\right)$ in a maize cultivation increased the length of cobs (11.4 cm on average). The highest cob length value recorded was $14.5 \mathrm{~cm}$, obtained with $\mathrm{N}_{40+80} \mathrm{P}_{40}$ fertilization, compared to other fertilizers used [34]. Similar average cob length values were obtained by Gao et al. [1] with the use of biogas and artificial fertilizers $(20.5 \mathrm{~cm})$.

\subsection{Thousand Kernel Weight (TKW)}

In the present study, different numbers of light exposure replications affected the value of thousand kernel weight. It ranged from $440 \mathrm{~g}$ to $476 \mathrm{~g}$. In a study by et al. [35] the reported TKW ranged from 81 to $322 \mathrm{~g}$. In another literature report [1], the thousand kernel weight increased after the use of a biogas suspension, humic substance, artificial fertilizers, and combinations thereof, and ranged between $203 \mathrm{~g}$ and $322 \mathrm{~g}$. Dziamba et.al [26] reported that the effect of irradiation on the weight of 1000 kernels depending on maize variety. The weight of one TKW ranged from 262 to $292 \mathrm{~g}$. A slight increase in wheat grain weight for three times exposure of red light, which amounted to $3.8 \%$ compared to the control was reported in study of Makarska [36].

\section{Conclusions}

The applied red light treatment led to an increase of the yield quantity and quality. The best effects were observed after 2-time exposure to light stimulation with the yields from Shaker and Powerhouse cultivars increasing. In terms of marketable yield, the highest increase was observed after K1 treatment for Powerhouse and Basin plants.

Light stimulation had a positive impact on corn cobs length, with the best results recorded for K1 treatment (Powerhouse, Basin) and K2 treatment (Shaker).

The thousand kernel weight recorded for the three corn cultivars was also increased after light treatment. The highest TKW values were recorded for the K2 (Shaker) and K3 (Powerhouse and Basin) treatment modes.

The obtained results may be utilized in the context of agrotechnical treatment applicable in eco-friendly agriculture, with the view of enhancing the sowing material.

Author Contributions: All authors have read and agree to the published version of the manuscript. Conceptualization, M.S. and A.D.-H.; methodology, M.S.; software, J.S.; validation, M.S., A.D.-H., and J.S.; formal analysis, A.D.-H.; investigation, M.S. and A.D.-H.; resources, M.S.; data curation, A.D.-H.; writing-original draft preparation, M.S.; writing — review and editing, M.S. and A.D.-H.; visualization, J.S.; supervision, J.S.

Funding: This research was funded by The University of Life Sciences in Lublin.

Conflicts of Interest: The authors declare no conflict of interest.

\section{References}

1. Gao, C.; El-Sawah, A.M.; Ali, D.F.I.; Hamoud, Y.A.; Shaghaleh, H.; Sheteiwy, M.S. The integration of bio and organic fertilizers improve plant growth, grain yield, quality and metabolism of hybrid maize (Zea mays L.). Agronomy 2020, 10, 319. [CrossRef]

2. Rosa, R. Quality of sweet corn yield depending on winter catch crops and weed control method. Acta Sci. Pol. Hortorum Cultus 2015, 14, 59-74.

3. Datta, D.; Chandra, S.; Singh, G. Yield and quality of sweet corn under varying irrigation regimes, sowing methods and moisture conservation practices. J. Pharmacogn. Phytochem. 2019, 8, 1185-1188.

4. Williams, M.M. Biological significance of low weed population densities on sweet corn. Agron. J. 2010, 102, 464-468. [CrossRef]

5. Krawiec, M.; Dziwulska-Hunek, A.; Kornarzyński, K. The use of physical factors for seed quality improvement of horticultural plants. J. Hort. Res. 2018, 26, 81-94. [CrossRef] 
6. Siyami, R.; Mirshekari, B.; Farahvash, F.; Rashidi, V.; Tarinejad, A. The effect of physical priming of seed on traits and yield of corn (Zea Mays L.) under water deficit conditions in Iran. Appl. Ecol. Environ. Res. 2018, 16, 617-627. [CrossRef]

7. Hanafy, M.S.; Husein, G.; Abdelmoty, E. Effect of $50 \mathrm{~Hz} 6 \mathrm{kV} / \mathrm{m}$ electric field on the protein molecular structureand the growth characteristics of the broad bean. Phys. Alive 2005, 13, 41-54.

8. Pietruszewski, S.; Muszynski, S.; Dziwulska, A. Electromagnetic fields and electromagnetic radiation as non-invasive external stimulants for seeds (selected methods and responses). Int. Agrophys. 2007, 21, 95-101.

9. Dziwulska-Hunek, A.; Kornarzyński, K.; Matwijczuk, A.; Pietruszewski, S.; Szot, B. Effect of laser and variable magnetic field simulation on amaranth seeds germination. Int. Agrophys. 2009, 23, 229-235.

10. Hernández, A.C.; Carballo, C.A.; Artola, A.; Michtchenko, A. Laser irradiation effects on maize seed field performance. Seed Sci. Technol. 2006, 34, 193-197. [CrossRef]

11. Hernández, A.C.; Dominguez, P.A.; Cruz, O.A.; Ivanov, R.; Carballo, C.A.; Zepeda, B.R. Laser in agriculture. Int. Agrophys. 2010, 24, 407-422.

12. Isaac, A.E.; Hernández, A.C.; Domínguez, P.A.; Cruz, O.A. Effect of pre-sowing electromagnetic treatment on seed germination and seedling growth in maize (Zea mays L.). Agron. Colomb. 2011, 29, 213-220.

13. Matwijczuk, A.; Kornarzyński, K.; Pietruszewski, S. Effect of magnetic field on seed germination and seedling growth of sunflower. Int. Agrophys. 2012, 26, 271-278. [CrossRef]

14. Pietruszewski, S.; Martinez, E. Magnetic field as a method of improving the quality of sowing material: A review. Int. Agrophys. 2015, 29, 377-389. [CrossRef]

15. Govindaraj, M.; Masilamani, P.; Alex Albert, V.; Bhaskaran, M. Effect of physical seed treatment on yiled and quality of crops: A review. Agric. Rev. 2017, 38, 1-14.

16. Hasan, M.; Hanafiah, M.M.; Taha, Z.A.; AlHilfy, I.H.H.; Said, M.N.M. Laser irradiation effects at different wavelengths on phenology and yield components of pretreated maize seed. Appl. Sci. 2020, 10, 1189. [CrossRef]

17. Gładyszewska, B. Estimation of laser biostimulation dose. Int. Agrophys. 2011, 25, 403-405.

18. Khan, A.; Khalili, S.K.; Khan, A.Z.; Marwat, K.B.; Afzal, A. The role of seed priming in semi- arid area for mung beam phenology and yield. Pak. J. Bot. 2008, 40, 2471-2480.

19. Gao, J.; Shi, J.; Dong, S.; Liu, P.; Zhao, B.; Zhang, J. Grain yield and rot characteristics of summer maize (Zea mays L.) under shade stress conditions. J. Agron. Crop. Sci. 2017, 203, 562-573. [CrossRef]

20. Zarębski, Z.W.; Dziamba, S. Sposób przedsiewnej obróbki ziarna i urządzenie do przedsiewnej obróbki ziarna (In Polish). Urząd Patentowy Rzeczypospolitej Polskiej. Patent 17092928 February 1997.

21. PN-R-75377:1996. Kukurydza cukrowa (In Polish). Polska Norma. Available online: https://sklep.pkn.pl/pnr-75377-1996p.html (accessed on 30 April 2020).

22. Yang, Y.; Xu, W.; Hou, P.; Liu, G.; Liu, W.; Wang, Y.; Zhao, R.; Ming, B.; Xie, R.; Wang, K.; et al. Improving maize grain yield by matching maize growth and solar radiation. Sci. Rep. 2019, 9, 3635. [CrossRef]

23. Gao, J.; Zhao, B.; Dong, S.; Liu, P.; Ren, B.; Zhang, J. Response of summer maize photosynthate accumulation and distribution to shading stress assessed by using $13 \mathrm{CO} 2$ stable isotope tracer in the field. Front. Plant Sci. 2017, 8, 1821. [CrossRef]

24. Yang, H.; Shi, Y.; Xu, R.; Lu, D.; Lu, W. Effects of shading after pollination on kernel filling and physicochemical quality traits of waxy maize. Crop J. 2016, 4, 235-245. [CrossRef]

25. Jia, S.; Li, C.; Dong, S.; Zhang, J. Effects of shading at different stages after anthesis on maize grain weight and quality at cytology level. Agric. Sci. China 2011, 10, 58-69. [CrossRef]

26. Dziamba, S.; Dziamba, M.; Machaj, H.; Klimek, A. The influence of pre-sowing stimulation of seeds with light on yielding of some maize varieties. Biul. Inst. Hod. Aklim. Roślin 2004, 231, 445-451. (In Polish)

27. Makarska, E.; Michalak, M.; Wesołowska-Trojanowska, M. Wpływ światła lasera na wartość siewną oraz poziom antyoksydantów wybranych odmian pszenicy ozimej. Acta Agrophys. 2004, 4, 407-417. (In Polish)

28. Wesołowski, M.; Cierpiała, R. Przedsiewne naświetlanie laserem nasion pszenicy ozimej a jej plonowanie. Acta Agrophys. 2006, 8, 1031-1040. (In Polish)

29. Abbas, H.; Ranjan, R.S. Effect of overhead irrigation on corn yield and quality under shallow water table conditions. Can. Biosyst. Eng. 2016, 58, 33-44. [CrossRef]

30. Brum, M.D.S.; Cunha, V.D.S.; Stecca, J.D.L.; Grando, L.F.T.; Martin, T.N. Compoents of corn crop yiels under inoculation with Azospirllum brasilense using integrated crop-livestock system. Acta Sci. Agron. 2016, 38, 485-492. [CrossRef] 
31. Hernández, A.C.; Rodríguez, P.C.L.; Domínguez-Pacheco, F.A.; Hernández, A.A.M.; Cruz-Orea, A.; Carballo, C.A. Laser light on the mycoflora content in maize seeds. Afr. J. Biotechnol. 2011, 10, 9280-9288. [CrossRef]

32. Ramachandrappa, B.K.; Nanjappa, H.V.; Shivakumar, H.K. Yield and quality of baby corn (Zea Mays L.) as influenced by spacing and fertilization levels. Acta Agron. Hung. 2004, 52, 237-243. [CrossRef]

33. Prisecaru, G.; Sala, F. Response model of vegetation parameters and yield in maize under the influence of Lithovit fertilizer. AIP Conf. Proc. 2017, 1863, 430005. [CrossRef]

34. Bâşa, A.G.; Ion, V.; Dumbravă, M.; Temocico, G.; Epure, L.I.; Dumitru, S. Grain yield and yield components at maize under different preceding crops and nitrogen fertilization conditions. Agric. Agric. Sci. Proc. 2016, 10, 104-111. [CrossRef]

35. Karthik, S.K.; Mahesh, T.; Sumanth, B.; Tanmay, M. Study of physical and engineering properties of corn (Zea mays). Bull. Env. Pharmacol. Life Sci. 2017, 6, 404-409.

36. Makarska, E. Wpływ światła lasera na wskaźniki jakości technologicznej dwóch odmian pszenicy ozimej. Acta Agrophys. 2009, 14, 137-144. (In Polish)

(C) 2020 by the authors. Licensee MDPI, Basel, Switzerland. This article is an open access article distributed under the terms and conditions of the Creative Commons Attribution (CC BY) license (http://creativecommons.org/licenses/by/4.0/). 